\title{
Primary Synovial Sarcoma (SS) of the digestive system: a molecular and clinicopathological study of fifteen cases
}

\author{
Salvatore Romeo ${ }^{1}$, Sabrina Rossi ${ }^{1}$, Marthelena Acosta Marín², Fabio Canal', Marta Sbaraglia', Licia Laurino ${ }^{1}$, \\ Guido Mazzoleni ${ }^{3}$, Maria Cristina Montesco ${ }^{4}$, Laura Valori ${ }^{1}$, Marta Campo Dell'Orto ${ }^{1}$, Andrea Gianatti ${ }^{5}$, \\ Alexander Joseph Lazar ${ }^{2}$ and Angelo Paolo Dei Tos ${ }^{1 *}$
}

\begin{abstract}
Background: Recently a few cases of synovial sarcoma (SS) of the abdominal viscera have been reported, raising awareness about the potential for confusion between this entity and KIT-negative gastrointestinal stromal tumors (GIST). We report the clinicopathological, immunophenotypical and molecular features of fifteen more SS occurring in the stomach (8 cases), epigastric region (one case), small intestine (one case), large intestine (three cases), involving both the terminal ileum and the caecum (one case) and liver (one case).

Methods: Immunostains for SMA, DESMIN, CD34, CD117, S100, EMA, CK AE1/3, TLE1, CD56, CD99, BCL2, DOG1 were performed. Rearrangement of SS18 gene region was screened in all cases: by conventional karyotype in one case, the remaining cases were screened either by interphase FISH or Q-PCR or both.

Results: Ten patients were male and five female, with an age range of 17-61 years (median 44). Tumor size ranged from 2 to $15 \mathrm{~cm}$ (median 8). Mitoses per $10 \mathrm{HPF}$ ranged from 4 to 27 (median 9.5). Eleven tumors were monophasic fibrous SS, one biphasic SS and three poorly differentiated SS. SMA, Desmin, CD34, CD117 and S100 were negative in all cases, whereas EMA and/or CK AE1/AE3 were positive in all cases. TLE1, BCL2 and CD56 were positive in all tested cases. DOG1 was positive in one case. SS18 gene region rearrangement was demonstrated in all cases. A fusion transcript was amplified in eight cases: either SS18-SSX2 or SS18-SSX1 respectively in four cases each.
\end{abstract}

Conclusions: SS is increasingly recognized at visceral sites. Molecular analyses play a key role when dealing with usual histotypes in unusual sites. Correct diagnosis is crucial for appropriate therapy.

Keywords: Synovial sarcomas, Pathology, Differential diagnosis, Digestive tract, Sarcoma

\section{Introduction}

Synovial sarcoma (SS) is a mesenchymal malignant tumour that accounts for approximately $10 \%$ of all soft tissue sarcomas [1]. It usually occurs in the lower limbs of children and young adults, with the knee region being the most frequently affected area [1]. Three main histological variants of SS have been recognized: the monophasic, biphasic and poorly differentiated subtypes [1]. Both the monophasic and biphasic variants feature a spindle cell population set in a variable collagenous background with

\footnotetext{
* Correspondence: apdeitos@ulss.tv.it

'Department of Pathology, Treviso Regional Hospital, Piazza Ospedale 1, 31100 Treviso, Italy

Full list of author information is available at the end of the article
}

a hemangiopericytoma (HPC)-like vascular pattern [1]. An epithelial component is present in the biphasic variant, with solid nests and glandular or tubular structures [1]. The existence of a predominantly monophasic epithelial pattern has been reported, too [2]. In approximately $20 \%$ of cases, SS exhibits undifferentiated, high-grade morphology and is usually indicated as "poorly differentiated" SS (PDSS) [3]. Three main groups of PDSS can be identified: one exhibiting round cell morphology associated with necrosis and high mitotic count; another characterized by the presence of larger cells, with polygonal cytoplasm which may feature rhabdoid morphology; and a third group presenting as high-grade spindle cell tumors often featuring a "herringbone" growth pattern $[3,4]$.

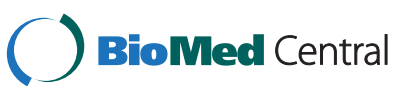

(C) 2015 Romeo et al.; licensee BioMed Central. This is an Open Access article distributed under the terms of the Creative Commons Attribution License (http://creativecommons.org/licenses/by/4.0), which permits unrestricted use, distribution, and reproduction in any medium, provided the original work is properly credited. The Creative Commons Public Domain Dedication waiver (http://creativecommons.org/publicdomain/zero/1.0/) applies to the data made available in this article, unless otherwise stated. 
SS subtypes share a common genetic alteration: a translocation involving chromosomes $\mathrm{X}$ and 18 . This translocation results in three alternative fusion products of the SS18 gene (previously known as SYT) (on chromosome 18) with either SSX1, or SSX2 or SSX4 gene (on chromosome X) [1]. This knowledge provides useful ancillary diagnostic tools [1] for identification of the specific translocation by interphase FISH analysis, with probes flanking the breakpoints, and amplification of the specific chimeric transcript by RT-PCR techniques [5].

SS rarely occurs in unusual sites including: the head and neck region [6,7], mediastinum [8], larynx and hypopharynx [9], nerves [10], blood vessels [11,12], heart [13], abdominal cavity [14], gastrointestinal tract [15-23] and liver $[24,25]$. In routine activity it may be difficult to distinguish SS occurring in the digestive tract from other mesenchymal neoplasms, mainly GIST (gastrointestinal stromal tumour). However, this distinction is crucial to ensure a correct therapeutic approach. Here we report the clinicopathological, immunohistochemical and molecular genetic data of fifteen cases of SS occurring in the digestive system. We aim to improve knowledge on this entity and stress the importance of correct differential diagnosis for appropriate therapeutic management.

\section{Materials and methods}

\section{Patients}

Fifteen cases of SS of the abdominal viscera were collected from three Italian institutions, the consultation files of one of the Authors (APDT) and Departments of Pathology, The University of Texas M. D. Anderson Cancer Center, Houston, TX, USA. Patients' clinical records were retrieved. Follow-up information was available for 11 patients (Table 1). All samples were handled in a coded fashion, and all procedures were performed according to the ethical guidelines of the local institutions.

\section{Pathology assessment and immunohistochemistry}

All the cases were reviewed for diagnostic confirmation and both necrosis extent and mitoses count evaluated, grading provided according to French National Federation of Cancer Centers (FNLCC) (Table 2). In a subset of cases neoadjuvant chemotherapy was applied and prechemo biopsies were not available (Table 2); the values for mitoses and necrosis are no longer relevant for these cases as pre-treated specimens cannot be accurately graded under the FNCLCC system.

Immunostaining was performed for EMA, cytokeratin AE1/AE3, SMA, Desmin, CD34, CD117, S-100, CD99, CD56 and TLE1. Four- $\mu \mathrm{m}$ sections of formalin-fixed paraffin-embedded material were used according to standard laboratory procedures. Details of the antibodies used are given in Table 3.

\section{Conventional karyotype}

For case 14 conventional karyotype was performed. Cell culture, harvest conditions, and karyotyping were performed according to standard protocols.

\section{Interphase FISH}

Fluorescent in situ hybridisation (FISH) was performed on $5 \mu \mathrm{m}$ paraffin-embedded tissue sections using the LSI SYT (18q11.2) Dual Color Break Apart Rearrangement Probe set (Vysis, Downers Grove, IL, USA).

Table 1 Clinicopathologic features of 14 synovial sarcomas of the digestive system

\begin{tabular}{llllll}
\hline Case \# & Site & Size & Gender & Age & Follow up \\
\hline 1 & Gastric body & 8 & $\mathrm{~F}$ & 50 & Lost \\
2 & Cardias & 6 & $\mathrm{M}$ & 36 & AWD@36 \\
3 & Gastric & 2 & $\mathrm{M}$ & 37 & Recent \\
4 & Gastric & $\mathrm{NR}$ & $\mathrm{M}$ & 26 & AWD@185 Liver \\
5 & Gastric & 10 & $\mathrm{M}$ & 58 & DOD@6 \\
6 & Gastric & 10 & $\mathrm{M}$ & 21 & Lost@48 \\
7 & Gastric & 6 & $\mathrm{M}$ & Lost@12 \\
8 & Gastric & 3.8 & $\mathrm{~F}$ & 36 & Recent \\
9 & Epigastrium & 13 & $\mathrm{~F}$ & 54 & AWD@7 \\
10 & lleum & 8 & $\mathrm{M}$ & 57 & DOD@60 \\
11 & Large bowel & 5.5 & $\mathrm{M}$ & 49 & NED@132 \\
12 & Rectosigmoid colon & 6.3 & $\mathrm{~F}$ & 40 & DOD@47 \\
13 & Rectosigmoid colon & 6.3 & $\mathrm{~F}$ & 44 & DOD@47 \\
14 & lleum/Colon & 7.5 & $\mathrm{M}$ & 44 & NED@108 \\
15 & Liver & 15 & $\mathrm{M}$ & 17 & AWD@12 \\
\hline
\end{tabular}


Table 2 Morphological features of 15 synovial sarcomas of the digestive system

\begin{tabular}{|c|c|c|c|c|c|c|c|}
\hline \multirow[t]{2}{*}{ Case \# } & \multirow[t]{2}{*}{ Type } & \multirow[t]{2}{*}{ Mitoses } & \multirow[t]{2}{*}{ Necrosis } & \multirow[t]{2}{*}{ Grading } & \multicolumn{3}{|l|}{ Involvement of } \\
\hline & & & & & Perivisceral soft tissue & Peritoneum & Adjacent organ \\
\hline 1 & M & 7 & 1 & 2 & None & None & None \\
\hline 2 & PD & 11 & 1 & 2 & Adventitial tissue & Yes & None \\
\hline 3 & M & 6 & 0 & 2 & None & None & None \\
\hline 4 & M & $P$ & $P$ & $P$ & Adventitial tissue & Yes & Pancreas \\
\hline 5 & M & 12 & 1 & 2 & Adventitial tissue & Yes & Pancreas \\
\hline 6 & M & $P$ & $P$ & $P$ & None & None & None \\
\hline 7 & B & 27 & 1 & 3 & None & None & None \\
\hline 8 & M & 14 & 1 & 2 & None & None & None \\
\hline 9 & M & 8 & 2 & 3 & Stomach, duodenum and liver & Yes & None \\
\hline 10 & M & 5 & 1 & 2 & None & None & None \\
\hline 11 & M & 13 & 1 & 2 & Perivisceral adipose tissue & None & None \\
\hline 12 & PD & $P$ & $P$ & $P$ & Perirectal adipose tissue & None & None \\
\hline 13 & PD & $P$ & $P$ & $P$ & None & None & None \\
\hline 14 & M & 4 & 1 & 2 & None & None & None \\
\hline 15 & M & $P$ & $P$ & $P$ & None & None & None \\
\hline
\end{tabular}

Legend: M: monophasic, B: biphasic, PD: poorly differentiated, mitoses are per 10 HPF, P: pretreated. Necrosis is reported as: 0 for no necrosis, 1 for <50\% tumor necrosis, 2 for $\geq 50 \%$ tumor necrosis.

Hybridisation was performed according to the manufacturer's protocol. Slides were mounted and counterstained with anti-fade DAPI (Vysis, Downers Grove, IL, USA), visualized using an epifluorescent microscope (Olympus BX61) and analysed with FISH analysis software (GenetixCytovision 4.5.1). 300 interphase nuclei were analyzed.

\section{Q-PCR}

Ten to fifteen $15 \mu$ m-thick sections from paraffinembedded tissue were de-paraffinized twice using $x y-$ lene, washed twice with absolute ethanol followed by TNE1X, resuspended in $250 \mu$ l of ATL buffer (Qiagen) with the addition of proteinase $\mathrm{K}$ (Qiagen), and incubated for 72 hours at $55^{\circ} \mathrm{C}$ under moderate shaking. The percentage of tumor cells, as calculated from the HEstained slides, was at least $70 \%$. Subsequently, RNA was extracted with TRIzol-LS Reagent (Gibco BRL), according to the manufacturer's instructions. RNA pellets were resuspended in 10-20 $\mu \mathrm{l}$ of RNAse-free water and stored at $-80^{\circ} \mathrm{C} .5 \mu \mathrm{g}$ of total RNA were reverse transcribed in a total volume of $20 \mu \mathrm{l}$ using specific reverse primers for $S S X$ and BETA2M genes, respectively. Samples were incubated at $42^{\circ} \mathrm{C}$ for 1 hour, then at $72^{\circ} \mathrm{C}$ for 15 minutes. PCR amplification of each sample and a 1:20 dilution were performed in duplicate using 96-well plates in $25 \mu \mathrm{l}$ reaction mixture containing $300 \mathrm{nM}$ of each primer, $200 \mathrm{nM}$ of each probe (SSX1-SSX2) or $100 \mathrm{nM}$ probe BETA2M and 2X TaqMan Gene Expression Master Mix

Table 3 Details of the antibodies used in this study

\begin{tabular}{lllll}
\hline Antibody & Clone & Producer & Diluition & Antigen retrieval \\
\hline EMA & E29 & Dako, Glostrup, Denmark & Prediluted & Flex (Dako) \\
CKAE1/AE3 & Polyclonal & Dako, Glostrup, Denmark & Prediluted & Flex (Dako) \\
SMA & 1A4 & Dako, Glostrup, Denmark & Prediluted & Flex (Dako) \\
DESM & D33 & Dako, Glostrup, Denmark & Prediluted & Flex (Dako) \\
CD34 & QBend-10 & Dako, Glostrup, Denmark & prediluited & Flex (Dako) \\
CD117 & Polyclonal & Dako, Glostrup, Denmark & $1 / 700$ & Flex (Dako) \\
S-100 & Polyclonal & Dako, Glostrup, Denmark & Prediluted & Flex (Dako) \\
TLE1 & C-9121 & Santa Cruz Biochemicals, Santa Cruz, CA, USA & $1: 100$ & Flex (Dako) \\
BCL2 & 124 & Dako, Glostrup, Denmark & Prediluted & Flex (Dako) \\
CD56 & $123 C 3$ & Dako, Glostrup, Denmark & Prediluted & Flex (Dako) \\
CD99 & MIC2 & Dako, Glostrup, Denmark & Prediluted & Flex (Dako) \\
DOG1 & K9 & Novocastra, NewCastle, UK & 1:100 & Flex (Dako) \\
\hline
\end{tabular}


(Applied Biosystems, CA), on Applied Biosystems StepOnePlus Real-Time PCR Systems (Applied Byosystem). (For primer and probe sequences, see Table 4). Thermal cycling conditions were 2 minutes at $50^{\circ} \mathrm{C}, 10$ minutes at $95^{\circ} \mathrm{C}$, then 50 cycles for three PCR steps consisting of 30 seconds at $95^{\circ} \mathrm{C}$ and 1 minute at $60^{\circ} \mathrm{C}$. Eight cases were studied by Q-PCR, for all of them a positive control product was amplified.

\section{Results}

In the identified fourteen cases of digestive system SS a male prevalence was found: male/female ratio was 3:1. Age at clinical presentation ranged from 17 to 61 years (median 44 years) (Table 1). Size ranged from $2 \mathrm{~cm}$ to $15 \mathrm{~cm}$ (median $8 \mathrm{~cm}$ ) (Table 1). Eight cases were occurring in the stomach, one case in the epigastric region, one case in the ileum, three cases in the large intestine, one case was involving both the terminal ileum and the caecum and one case in the liver (Table 1).

Five of the eight tumors arising in the stomach tract were confined to the wall (without serosal involvement); one extended into the perivisceral soft tissue, peritoneum and omentum (Figure 1A) and two involved the pancreas (Table 2). The tumor located in the epigastric region was adherent to the stomach and duodenal wall and focally attached to the liver (Table 2). Three tumors were involving the large bowel with extension in the perivisceral adipose tissue in two of them. The case affecting the ileum was limited to the ileum wall, similarly also the case involving both ileum and caecum was limited to the visceral wall (Table 2). The one in the liver was confined to the parenchyma without ulceration of the Glisson's capsule (Table 2).

Microscopically, eleven of the tumours consisted of monotonous spindle cell proliferation, with scant intercellular eosinophilic collagenous stroma (Figure 1B) (Table 2). A focal HPC-like vascular network was observed. Three cases showed poorly differentiated features (Figure 1C) and one showed biphasic features with both spindle cells components and tubules formation (Table 2).

Table 4 Sequences of the primers and probes used in this study

\begin{tabular}{ll}
\hline PRIMER/PROBE name & Sequence \\
\hline SS18 (forward) & AGAGGCCTTATGGATATGACCAGAT \\
SSXC (reverse) & CRTITTGTGGCCAGATGC \\
BETA2M+ (forward) & TGACTITGTCACAGCCCAAGATA \\
BETA2M- (reverse) & AATCCAAATGCGGCATCTTC \\
SSX1 probe & TCCCTTCGAATCATITCGTCCTCTGCT \\
SSX2 probe & TCTGGCACTTCCTCCGAATCATTTCCT \\
BETA2M probe & TGATGCTGCTTACATGTCTCGATCCCA \\
\hline
\end{tabular}

Mitotic count ranged from 4 to 27 mitoses/10 HPF (median 9.5) (Table 2). Immunoreactivity for EMA was found in all tested cases ranging from focal to strong and diffuse (Figure 1D) (Table 5). Focal positivity for immunostains for cytokeratin AE1-AE3 was found in 8 cases (Table 5). All tested cases were positive for TLE1, BCL2 and CD99 (Table 5). No expression of CD117, SMA, DESMIN, CD34 and S-100 protein was found. DOG1 was focally expressed in one case (case 9, Table 5).

All cases showed SS18 gene region rearrangement. Case 14 showed $46, \mathrm{XY}, \mathrm{t}(\mathrm{X} ; 18)(\mathrm{p} 11 ; \mathrm{q} 11)$ karyotype (data not shown). The remaining cases were assessed either by interphase FISH (Figure 1E) or by RT-PCR or both. Eight cases were analyzed by RT-PCR: either SS18SSX2 fusion transcript or SS18-SSX1 fusion transcript was identified in 4 cases each (Figure 1F, Table 5).

Follow up was available for 11 patients: range from 6 to 185 months (47 median) (Table 1 ).

Based on clinical, morphological, immunophenotypical and molecular data a diagnosis of primary SS of the digestive tract was formulated: monophasic synovial sarcoma in eleven cases, biphasic SS in one case and poorly differentiated SS in three cases.

\section{Discussion}

SS is characterized by a complex, relatively distinctive immunophenotype, which includes co-expression of mesenchymal (vimentin) and epithelial markers (cytokeratins and EMA). Since morphological features of epithelial differentiation may be very subtle, immunostains are a valuable diagnostic aid. Cytokeratins tend to decorate most biphasic synovial sarcomas, but when dealing with the monophasic subtype, the percentage of immunopositivity falls to $60 \%-70 \%$. Interestingly, cytokeratin immunoreactivity has been demonstrated only in $50 \%$ of PDSS [3] and high molecular weight cytokeratins proved to be more sensitive than low molecular weight cytokeratins. The most sensitive marker of epithelial differentiation is EMA, which stains most cases of PDSS, including those that fail to express cytokeratins [3]. Between $30 \%$ and $60 \%$ of SS express S-100 protein leading to potential confusion when dealing with the differential diagnosis between monophasic spindle-cell SS and MPNST [26,27]. To avoid diagnostic pitfalls caused by the use of single antibody, it is therefore strongly recommended to perform a panel of immunohistochemical markers.

The diagnosis of biphasic synovial sarcoma is usually straightforward, even for cases occurring in the digestive system. Regarding monophasic SS in the digestive system, the main differential diagnosis is with GIST: any mesenchymal lesion arising in the GI tract would naturally be suggestive of a diagnosis of GIST and CD117 negativity "per se" does not rule out such a possibility 


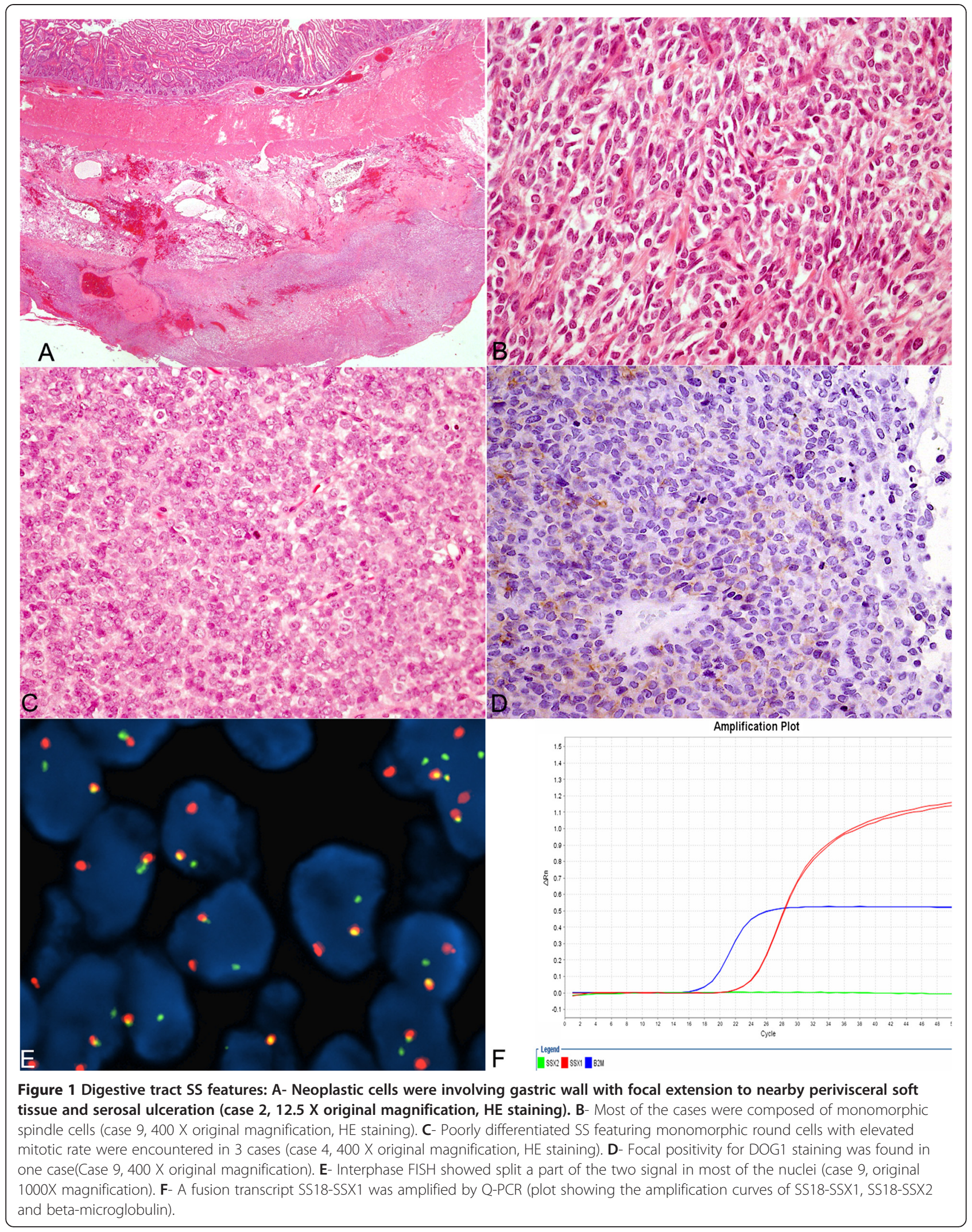


Table 5 Results of the performed immunostains and fusion type in $\mathbf{1 5}$ synovial sarcomas of the digestive system

\begin{tabular}{|c|c|c|c|c|c|c|c|c|c|c|c|c|c|}
\hline Case \# & EMA & CKAE1/AE3 & SMA & DESMIN & CD34 & CD117 & S-100 & BCL2 & CD99 & CD56 & DOG1 & TLE1 & Fusion type \\
\hline 1 & + & - & - & - & - & - & - & + & + & + & - & + & SS18-SSX1 \\
\hline 2 & + & - & - & - & - & - & - & + & + & + & - & + & $\mathrm{N} / \mathrm{A}$ \\
\hline 3 & + & + & - & - & - & - & - & + & + & + & - & + & $\mathrm{N} / \mathrm{A}$ \\
\hline 4 & + & - & NP & NP & NP & - & - & $N P$ & NP & $N P$ & NP & NP & $\mathrm{N} / \mathrm{A}$ \\
\hline 5 & + & - & NP & - & - & - & - & NP & NP & NP & $N P$ & $N P$ & SS18-SSX1 \\
\hline 6 & + & - & $N P$ & $N P$ & NP & - & - & $N P$ & NP & $N P$ & $N P$ & NP & $\mathrm{N} / \mathrm{A}$ \\
\hline 7 & NP & + & $N P$ & NP & - & - & NP & $N P$ & NP & $N P$ & $N P$ & $N P$ & SS18-SSX2 \\
\hline 8 & + & + & - & - & - & - & - & + & + & + & - & + & SS18-SSX1 \\
\hline 9 & + & + & - & - & - & - & - & + & + & + & + & + & $\mathrm{N} / \mathrm{A}$ \\
\hline 10 & + & + & - & - & - & - & - & + & + & + & - & + & SS18-SSX2 \\
\hline 11 & + & - & - & - & - & - & - & + & + & + & - & + & SS18-SSX2 \\
\hline 12 & + & + & $N P$ & $N P$ & $N P$ & - & - & + & + & $N P$ & $N P$ & $N P$ & SS18-SSX2 \\
\hline 13 & + & + & NP & $N P$ & $N P$ & - & - & + & + & $N P$ & $N P$ & $N P$ & SS18-SSX1 \\
\hline 14 & + & - & NP & - & - & - & - & + & + & $N P$ & NP & NP & $\mathrm{N} / \mathrm{A}$ \\
\hline 15 & + & + & - & - & - & - & - & + & + & + & - & + & N/A \\
\hline
\end{tabular}

[28]. GISTs are usually composed of short spindled and/ or epithelioid cells with perinuclear vacuolization and nuclear palisading. Recognition of the histological features, and the combination of CD117 with DOG1 staining is sufficient in the majority of cases to confirm the diagnosis of GIST [29]. However caution should be used in interpreting the results of immunohistochemistry since synovial sarcoma of the digestive system may show focal positivity for DOG 1 [30], as also exemplified in our case series. Remarkably sporadic GIST cases have been reported to be positive for cytokeratin [31,32], however EMA positivity is exceptional in GIST [23]. Leiomyosarcomas and malignant spindle cell melanomas are considered in the differential diagnosis with monophasic SS of the digestive system. However they are characterized by a higher pleomorphism and stronger immunostaining for smooth muscle markers and melanocytic markers, respectively, can usually confirm the diagnoses.

Sarcomatoid carcinoma may also be considered in the differential diagnosis, however it often exhibits conspicuous pleomorphism, stronger expression of epithelial markers, and area of conventional carcinoma are often associated with the sarcomatoid component.

Gastrointestinal clear cell sarcoma may be very difficult to distinguish form digestive system SS [33,34], also because, as previously mentioned, SS may be positive for S100 staining [26,27]. However gastrointestinal clear cell sarcomas are usually negative for epithelial markers and show rearrangement of the EWSR1 gene [33,34]. Remarkably clear cells sarcomas occurring in the gastrointestinal tract differ from clear cell sarcomas of the soft tissue. In fact they display scattered osteoclast-type giant cells and only partial melanocytic differentiation, being debated to be a separate entity. For this reason Stockman et al. proposed to call it malignant gastrointestinal neuroectodermal tumor [33].

PD SS may resemble other small round cell tumors including Ewing Sarcoma/PNET, neuroblastoma, rhabdomyosarcoma and lymphoma [1]. Remarkably CD99 antigen is found also in SS [35] and epithelial markers may be absent in PDSS and focally present in Ewing Sarcoma/PNET [1]. In this setting, demonstration of rearrangement of SSX18 or EWSR1 is crucial for differentiating respectively PDSS from Ewing Sarcoma/PNET [1]. Also it should be remembered that CD99 positivity in synovial sarcomas does not feature the typical crisp membrane staining most often observed in Ewing's sarcoma.

Cytogenetically, all SS variants are characterized by the reciprocal translocation $\mathrm{t}(\mathrm{X} ; 18)(\mathrm{p} 11.2 ; \mathrm{q} 11.2)$, which leads, at molecular level, to the fusion between the synovial sarcoma translocation gene on chromosome 18 (SS18) and one of the synovial sarcoma X breakpoint (SSX) genes on chromosome X: SSX1, SSX2 and rarely with SSX4 [36-38]. Interestingly, the SS18-SSX1 translocation seems to be associated with the biphasic type [39]. The SS18 gene is unrelated to any other known gene but contains a glutamine-proline-glycine-rich region, suggestive of a transcriptional activation domain. The SSX1, SSX2 and SSX4 genes are also unrelated to other known genes and encode proteins that show a remarkable homology.

Despite initial attempt to correlate fusion type with a significantly longer disease-free survival $[39,40]$ morphological grading is still the most important prognostic indicator [41]. Furthermore, tumor size $(>5 \mathrm{~cm})$, presence of neural infiltration and vascular invasion, p53 overexpression, and 
high Ki67 proliferation index identify subsets of SS patients with increased risk of tumor relapse [42-44].

\section{Conclusions}

Recognizing SS is of paramount importance to ensure the right therapy, especially because SS is known to respond to ifosfamide-based systemic treatments [45]. In the clinical setting of SS of the digestive system the use of ancillary molecular techniques improves the diagnostic accuracy.

\section{Competing interests}

The authors declare that they have no competing interests.

\section{Authors' contributions}

SR: experimental design, drafting of the manuscript; SR, FC, MAM, MS, LL, LV, MCDO: commenting on the final manuscript; GM, MCM, AG: collecting new cases; AL, APDT: collecting new cases, drafting and editing of the manuscript. All authors have read and given final approval of the version to be published.

\section{Author details}

1Department of Pathology, Treviso Regional Hospital, Piazza Ospedale 1 31100 Treviso, Italy. ${ }^{2}$ Departments of Pathology, The University of Texas M. D. Anderson Cancer Center, Houston, TX, USA. ${ }^{3}$ Department of Pathology, Bolzano Regional Hospital, Bolzano, Italy. ${ }^{4}$ Department of Pathology, Padua University Medical School, Padua, Italy. ${ }^{5}$ Department of Pathology, Ospedali Riuniti di Bergamo, Bergamo, Italy.

Received: 22 October 2014 Accepted: 11 January 2015

Published online: 12 February 2015

\section{References}

1. Suurmeijer AJH, de Bruijn D, Geurts van Kessel A, Miettinen MM. Synovial Sarcoma. Lyon: IARC Press; 2013.

2. Majeste RM, Beckman EN. Synovial sarcoma with an overwhelming epithelial component. Cancer. 1988;61:2527-31.

3. Folpe AL, Schmidt RA, Chapman D, Gown AM. Poorly differentiated synovial sarcoma: immunohistochemical distinction from primitive neuroectodermal tumors and high-grade malignant peripheral nerve sheath tumors. Am J Surg Pathol. 1998;22:673-82

4. Van de Rijn M, Barr FG, Xiong QB, Hedges M, Shipley J, Fisher C. Poorly differentiated synovial sarcoma: an analysis of clinical, pathologic, and molecular genetic features. Am J Surg Pathol. 1999;23:106-12.

5. Coindre JM, Pelmus M, Hostein I, Lussan C, Bui BN, Guillou L. Should molecular testing be required for diagnosing synovial sarcoma? A prospective study of 204 cases. Cancer. 2003;98:2700-7.

6. Batsakis JG, Nishiyama RH, Sullinger GD. Synovial sarcomas of the neck. Arch Otolaryngol. 1967;85:327-31.

7. Roth JA, Enzinger FM, Tannenbaum M. Synovial sarcoma of the neck: follow up study of 24 cases. Cancer. 1975;35:1243-53.

8. Witkin GB, Miettinen M, Rosai J. A biphasic tumor of the mediastinum with features of synovial sarcoma. A report of four cases. Am J Surg Pathol. 1989;13:490-9.

9. Dei Tos AP, Dal Cin P, Sciot R, Furlanetto A, Da Mosto MC, Giannini C, et al. Synovial sarcoma of the larynx and hypopharynx. Ann Otol Rhinol Laryngol. 1998;107:1080-5.

10. O'Connell JX, Browne WL, Gropper PT, Berean KW. Intraneural biphasic synovial sarcoma: an alternative "glandular" tumor of peripheral nerve. Mod Pathol. 1996;9:738-41.

11. Miettinen M, Santavirta S, Slatis P. Intravascular synovial sarcoma. Hum Pathol. 1987;18:1075-7.

12. Shaw GR, Lais CJ. Fatal intravascular synovial sarcoma in a 31-year-Old woman. Hum Pathol. 1993;24:809-10.

13. Hazelbag HM, Szuhai K, Tanke HJ, Rosenberg C, Hogendoorn PCW. Primary synovial sarcoma of the heart: a cytogenetic and molecular genetic analysis combining RT-PCR and COBRA-FISH of a case with a complex karyotype. Mod Pathol. 2004:17:1434-9.
14. Fetsch JF, Meis JM. Synovial sarcoma of the abdominal wall. Cancer 1993:72:469-77.

15. Amr SS, Shihabi NK, Al HH. Synovial sarcoma of the esophagus. Am J Otolaryngol. 1984:5:266-9.

16. Anton-Pacheco J, Cano I, Cuadros J, Vilarino A, Berchi F. Synovial sarcoma of the esophagus. J Pediatr Surg. 1996:31:1703-5.

17. Bloch MJ, lozzo RV, Edmunds Jr LH, Brooks JJ. Polypoid synovial sarcoma of the esophagus. Gastroenterology. 1987;92:229-33.

18. Habu S, Okamoto E, Toyosaka A, Nakai Y, Takeuchi M. Synovial sarcoma of the esophagus: report of a case. Surg Today. 1998:28:401-4.

19. Palmer BV, Levene A, Shaw HJ. Synovial sarcoma of the pharynx and oesophagus. J Laryngol Otol. 1983:97:1173-6.

20. Billings SD, Meisner LF, Cummings OW, Tejada E. Synovial sarcoma of the upper digestive tract: a report of two cases with demonstration of the X;18 translocation by fluorescence in situ hybridization. Mod Pathol. 2000;13:68-76.

21. Chan GS, Yuen ST, Chan KW. Synovial sarcoma presenting as a polypoid jejunal mass. Histopathology. 2004;44:191-3.

22. Schreiber-Facklam H, Bode-Lesniewska B, Frigerio S, Flury R. Primary monophasic synovial sarcoma of the duodenum with SYT/SSX2 type of translocation. Hum Pathol. 2007;38:946-9.

23. Makhlouf HR, Ahrens W, Agarwal B, Dow N, Marshalleck JJ, Lee EL, et al. Synovial sarcoma of the stomach: a clinicopathologic immunohistochemical, and molecular genetic study of 10 cases. Am J Surg Pathol. 2008;32:275-81

24. Srivastava A, Nielsen PG, Dal Cin P, Rosenberg AE. Monophasic synovial sarcoma of the liver. Arch Pathol Lab Med. 2005;129:1047-9.

25. Holla P, Hafez GR, Slukvin I, Kalayoglu M. Synovial sarcoma, a primary liver tumor-a case report. Pathol Res Pract. 2006;202:385-7.

26. Fisher C, Schofield JB. S-100 protein positive synovial sarcoma. Histopathology. 1991;19:375-7.

27. Guillou L, Wadden C, Kraus MD, Dei Tos AP, Fletcher CDM. S-100 protein reactivity in synovial sarcomas- a potentially frequent diagnostic pitfall: immunohistochemical analysis of 100 cases. Applied Immunohistochemistry. 1996:4:167-75

28. Medeiros F, Corless CL, Duensing A, Hornick JL, Oliveira AM, Heinrich MC et al. KIT-negative gastrointestinal stromal tumors: proof of concept and therapeutic implications. Am J Surg Pathol. 2004;28:889-94.

29. Novelli M, Rossi S, Rodriguez-Justo M, Taniere P, Seddon B, Toffolatti L, et al. DOG1 and CD117 are the antibodies of choice in the diagnosis of gastrointestinal stromal tumours. Histopathology. 2010;57:259-70.

30. Miettinen M, Wang ZF, Lasota J. DOG1 antibody in the differential diagnosis of gastrointestinal stromal tumors: a study of 1840 cases. Am J Surg Pathol. 2009:33:1401-8

31. Rossi G, Sartori G, Valli R, Bertolini F, Bigiani N, Schirosi L, et al. The value of c-kit mutational analysis in a cytokeratin positive gastrointestinal stromal tumour. J Clin Pathol. 2005;58:991-3.

32. Lippai N, Fule T, Nemeth T, Benedek G, Malyi I, Padi E, et al. Keratin-positive gastrointestinal stromal tumor of the stomach mimicking gastric carcinoma: diagnosis confirmed by c-kit mutation analysis. Diagn Mol Pathol. 2008;17:241-4

33. Stockman DL, Miettinen M, Suster S, Spagnolo D, Dominguez-Malagon $H$, Hornick $J$, et al. Malignant gastrointestinal neuroectodermal tumor: clinicopathologic, immunohistochemical, ultrastructural, and molecular analysis of 16 cases with a reappraisal of clear cell sarcoma-like tumors of the gastrointestinal tract. Am J Surg Pathol. 2012;36:857-68.

34. D’Amico FE, Ruffolo C, Romeo S, Massani M, Dei Tos AP, Bassi N. Clear cell sarcoma of the ileum: report of a case and review of the literature. Int J Surg Pathol. 2012;20:401-6.

35. Dei Tos AP, Wadden C, Calonje E, Sciot R, Pauwels P, Knight JC, et al. Immunohistochemical demonstration of glycoprotein p30/32 ${ }^{\text {mic2 }}$ (CD99) in synovial sarcoma. Appl Immunohistochem. 1995;3:168-73.

36. Crew AJ, Clark J, Fisher C, Gill S, Grimer R, Chand A, Shipley J, Gusterson BA, Cooper CS: Fusion of SYT to two genes, SSXI and SSX2, encoding proteins with homology to the Kruppel-associated box in human synovial sarcoma. EMBO J, in press.

37. Clark J, Rocques PJ, Crew AJ, Gill S, Shipley J, Chan AML, et al. Identification of novel genes, SYT and SSX involved in the $t(X ; 18)(p 11.2 ; q 11.2)$ translocation found in human synovial sarcoma. Nature Genet. 1994:7:502-8.

38. Fligman I, Lonardo F, Jhanwar SC, Gerald WL, Woodruff J, Ladanyi M. Molecular diagnosis of synovial sarcoma and characterization of a variant SYT-SSX2 fusion transcript. Am J Pathol. 1995;147:1592-9. 
39. Kawai A, Woodruff J, Healy JH, Brennan MF, Antonescu CR, Ladanyi M. SYT-SSX gene fusion as a determinant of morphology and prognosis in synovial sarcoma. N Engl J Med. 1998;338:153-60.

40. Ladanyi M, Antonescu CR, Leung DH, Woodruff JM, Kawai A, Healey JH, et al. Impact of SYT-SSX fusion type on the clinical behavior of synovial sarcoma: a multi-institutional retrospective study of 243 patients. Cancer Res. 2002;62:135-40.

41. Guillou L, Benhattar J, Terrier P, Gallagher G, Jundt G, Stauffer E, et al. SYT-SSX fusion type is not a prognostic factor in synovial sarcoma (SS) patients. A multi-institutional study of 182 cases. Mod Pathol. 2003;16:13A.

42. Antonescu CR, Leung DH, Dudas M, Ladanyi M, Brennan M, Woodruff JM, et al. Alterations of cell cycle regulators in localized synovial sarcoma: a multifactorial study with prognostic implications. Am J Pathol. 2000;156:977-83.

43. Lewis JJ, Antonescu CR, Leung DH, Blumberg D, Healey JH, Woodruff JM et al. Synovial sarcoma: a multivariate analysis of prognostic factors in 112 patients with primary localized tumors of the extremity. J Clin Oncol. 2000;18:2087-94.

44. Trassard M, Le DV, Hacene K, Terrier P, Ranchere D, Guillou L, et al. Prognostic factors in localized primary synovial sarcoma: a multicenter study of 128 adult patients. J Clin Oncol. 2001;19:525-34.

45. Ferrari A, Gronchi A, Casanova M, Meazza C, Gandola L, Collini P, et al. Synovial sarcoma: a retrospective analysis of 271 patients of all ages treated at a single institution. Cancer. 2004;101:627-34.

\section{Submit your next manuscript to BioMed Central and take full advantage of:}

- Convenient online submission

- Thorough peer review

- No space constraints or color figure charges

- Immediate publication on acceptance

- Inclusion in PubMed, CAS, Scopus and Google Scholar

- Research which is freely available for redistribution 